\title{
Globalization and Contemporary Mongolian Literature in China
}

\author{
Jinhua Bao \\ Personnel Division of Chifeng University
}

Keywords: Globalization; Cultural hegemony; Contemporary; Mongolian literature

\begin{abstract}
In the context of globalization, cultural hegemony deeply influences the contemporary Mongolian literature in China. In this paper, the condition, change and development of contemporary Mongolian literature are understood and positioned, the current situation and literature characteristics of contemporary Mongolian literature in several different historical stages are made the analogy study, and the change of the tradition and literature spirit of contemporary Mongolian literature and the path of "integration" with globalization are discussed.
\end{abstract}

\section{Introduction}

Globalization is a new phenomenon which has been increasingly highlighted all over the world since 1980s, and is the basic feature of the present era. In the process of defining the concept of globalization, just like the characteristics of globalization, it is full of instability and variability. But as a whole, globalization is a multiple concept that takes the economic globalization as the core and includes the interrelation, influence and restriction of different countries, nations and regions in the aspect of politics, culture, science and technology, military, security, ideology, lifestyle, values and so on. "Globalization" can be summarized as the globalization of ten aspects such as science and technology, economy, politics, rule of law, management, organization, culture, ideology, interpersonal communication and international relations.

\section{The Impact of Economic Globalization on the Country}

For developing nations and countries, economic globalization means not only the convenient opportunity that shares global resources, but also the pressures and challenges that are much greater than before. This impact comes at least from two aspects: the first one is the cultural colonization pushed by cultural imperialism in the era of economic globalization or the late capitalist period; the second one is the competition among multicultures.

The First One is the Cultural Colonization Pushed by Cultural Imperialism in the Era of Economic Globalization. When the world entered the post colonial era, the western developed countries changed from territorial colonization to cultural colonization. Under the influence of capital and interest, they made up and played again. Through abandoning the fierce images of guns and holding a sword of cultural invasion with the appearance full of tender feelings, the developed capitalist countries finally embarked on the cultural imperialism road that promoted the cultural colonization and sought the "cultural hegemony". They tried to convey the social system, life style, cultural ideology and political ideology based on United States to other countries by using the "soft power" of modern information technology such as communication media and cultural exchanges( $\mathrm{Li}$ Xiguang), and broke the cultural foundation on which the nation and country depend by changing the way of thinking and the concept of mind of people, so as to achieve the most thorough assimilation and conquest.

Because of the strong advantages of western culture, the discourse hegemony which is accompanied by consumerism has inexorably made all cultures be incorporated into a homogeneous western culture. The daily lives of modern Chinese people, including many minority writers, are accompanied by suits, ties, KFC, Carrefour, Sino-foreign joint venture car, Budweiser, lux and Durex. Even the international convention organizations representing justice and fairness have become tools for western developed countries to implement the strategy of cultural imperialism. Kapoor angrily said in the book "Globalization and Culture: Exploring the void" : "The term 
"globalism" shamelessly means a market ideology, which is controlled by the International Monetary Fund, the World Bank and the Executive Committee of the Group of Seven, and it reaches the peak of perfection through GATT. It also refers to a global market in which the United States which has "won" the cold war is a moral steward. It sets out the principles of free trade and defines the standards of human rights as well as the norms of historical and cultural studies in the same general pattern. So, what is being globalized is American style capitalism and its own worldview[1]".

The Italian, Gramsci, put forward the theory of cultural hegemony, the Palestinian American, Said, put forward the Orientalism, and even the famous historian, Toynbee, thought: "human beings should be different, so that human culture will be more colorful[2]". These opposing views argue that in the western capitalist society, the rule of the bourgeoisie no longer relies on violence, but relies on public opinion and its control over the cultural hegemony of the civil society.

The Second One is from the Propaganda that Abolishes National Languages. The national language is the national identity symbol, and the invasion of a nation and country is no more than a direct substitution for its national language. Some statistics show that more than two thirds of the world's scientists write in English. Three fourths of the world's mail is written in English, while 80\% of the information in the global electronic recovery system is stored in English. Today, if we don't speak English, we can't carry out the international exchange, so many non-English speaking countries have to incorporate English into their national education system[1]. Roy Weatherford, an American philosopher, was ecstatic to see it as the result dominated by America as a military, economic, and entertainment superpower, and he believed that this would guarantee world peace"the most fearful thing for patriotism and chauvinism around the world is about to become the reality: we will eventually become 'a world, a government and a culture"'. Thus, the language problem is no longer a simple communication, but has risen to the height of ideological output.

\section{The Situation, Change and Development of the Contemporary Mongolian Literature}

In the development of Mongolian literature, Mongolian literature has been confronted with the influence and pressure of the more powerful mainstream Chinese culture, and it was interpreted and misread in a dominant discourse at the beginning.

Mongolian contemporary literature is taken as the example. In the fifties, novelists represented by Ma Laqinfu, A Odser, Chaoketunaren, Peng Sike and Zhalagahu showed the grassland culture of Inner Mongolia with their own creation, attracted people's attention and got wide praise from the literary world. Objectively speaking, at that time, these novels were significantly different from those of Han writers in artistic conception and expression techniques. However, people show great tolerance for the defects of these novel's artistic forms. There are two reasons: the first one is that the Mongolian culture, relative to the mainstream culture, has been in disadvantaged and marginalized status of sympathy and tolerance. The second one is that the heterogeneous cultural landscape displayed by grassland culture novels satisfies the expectation of people for heterogeneous culture. What the people concern is not the art forms of these novels, but the alternative cultural landscapes in these novels - the features of grassland culture, the natural scenery of grasslands and the peculiar folk custom of the Mongol nationality.

The author's national identity and the cultural landscape in the novel are more attractive than his novel itself to some extent. Because of this, people can accept these authors' works, and the harshest critic will also forgive the inadequacy of their works and their creative ideas. Therefore, for the mainstream culture and the reading expectation of "others", the minority culture is a heterogeneous culture. Although these cultures are on the edge, most of them have their own historical inheritance. Some minority cultures once had historical memories of a strong culture, such as Mongolia culture, Qidan culture, Tibetan culture, Manchu culture and Hui culture. These memories stimulate the psychology of mainstream culture to some extent and make them have a strong desire to interpret the history of these cultures and the true forms of these heterogeneous culture, and these creations with national characteristics satisfy the "others" expectation of the strangeness of marginal and weak culture. 


\section{The Present Situation and Literary Features of Contemporary Mongolian Literature}

Literary works full of strong Mongolian folk culture are still the works which are favored by readers and critics with distinctive symbolic characteristics in the age of globalization. The standard of determinism, such as the boundless sky, vast plains, yurt, Mongolian oxcart, unique lifestyle characterized by moving their home along with grasses, large bowl of meat and large bowl of wine, is still the inherent attitude of the discourse hegemony. In the eyes of western discourse hegemony, China is the cheongsam, mandarin jacket, poverty and hunger, and the Mongolian naturally is the wrestling, herding and milking. This kind of misunderstanding lets the Mongols who no longer wear the Mongolia robe put on the Mongolia robe, lets the Mongols who have ridden the motorcycle put down the motorcycle and then ride horses, lets the Mongols who don't live in Mongolian yurt live in Mongolian yurt again and lets the Mongols who have already driven the tractor drive the Mongolian oxcart in order to satisfy the tourist's seeking novelty mentality. This phenomenon is a paradoxical and tragic cultural display of national culture in essence. On the one hand, this display shows the ingratiation of the weak culture on the strong culture. On the other hand, it increases the gap between the weak culture and the strong culture, so as to increase the degree of misreading.

Jiang Rong's Wolf Totem is the best-selling novel. The writer Zhang Kangkang commented that this book is a rich literary feast in detail. When we read the book, the pages are full of memorable literary details. Its unique, real, dense, vivid and accurate "character" is fascinating. The primitive grassland features of the millennium, white disaster and dark frost, the change of the four seasons grassland, the living habits of Mongolian herdsmen, the cruelty and warmth of wolves, the innocence and wisdom of the wolf, and the life styles and relationships of grassland horse, sheep dog, flock of sheep or goats, bull, marmot, hare, grassland mouse, swan and eagle form a number of independent and closely related countless wonderful stories, sketch out a true picture of grassland life, and realistically and artistically reproduce the cruelty and beauty of primitive nomadic grassland[3]. The Mongolia singer Teng Geer commented that "Wolf Totem" let me read the deep, bold, melancholy and long Mongolia tune and the sad and lonely cry of the prairie wolf. These are all the expression like a song of tragic warriors facing their God, and the most beautiful emotion, the most delicate words and the most touching love song.

\section{Conclusion}

Therefore, although the national character is opposed to the single homogeneous "world literature" advocated by the cultural colonists, it does not contradict with the "world literature" advocated by Marx and Goethe. The "world literature" said by Goethe is a collection of many national literature, but not a independent literary form. In the era of economic globalization, national literature will become stronger and stronger under the light of "world literature". The same is true of contemporary Mongolian literature. While maintaining the nationality, the Mongolian literature and other literature should learn and absorb from each other, so that the Mongolian literature will not become a lost lamb.

"Although I can not speak in my mother tongue, please accept my sadness, and my joy. I am also a child of the plateau, and there is a song in my heart. Also there is my father's grassland and mother's river in the song." The lyrics of a Mongolian song wrote a lot of contemporary Mongolian young people's living conditions, and the embarrassment and helplessness of those people who have forgotten the native language and characters. Literature is the art of language. Only by mastering a rich language and being good at extract accurate, concise and infectious language, can we create a vivid and moving artistic image and express the profound ideological content of social life clearly and accurately. Native language is the homeland of a nation forever, because it has the original thinking, emotion, cognition and other rich information of the nation. Heidegger said: "language is the existence of the home." We do not mention the impact of globalization for the time being, but just say the helpless of the domestic minority writers after encountering the Chinese language. Mother-tongue thinking and wisdom are shrinking day by day, and constantly break into the 
Chinese cultural discourse circle, therefore, it inevitably means the loss of the national language. The national felling that is difficult to abandon and the desire for modern pop culture are the problem of contradictory double aesthetic values. Perhaps it is the first question for us to think deeply about.

\section{References}

[1] J.G.Huo: National Culture and National Literature in the Age of Economic Globalization[J], Theory and Criticism of Literature and Art, 2007, (06).(In Chinese)

[2] Arnold Toynbee: A Study of History(illustrated edition)[M], Shanghai People's Publishing House, 2000.

[3] K.K.Zhang: The Psychology Novel and the Person's Self-examination Consciousness[M], China federation of literary and art circles publishing house, 2001.(In Chinese) 